\title{
The Effect of Using Alum Mordant in Wild Cherry Bark Dyestuff for the Production of UV Resistant Colored Paper
}

\section{Utjecaj aluminijskog fiksatora u bojilu od kore divlje trešnje na proizvodnju obojenog papira otpornoga na UV svjetlost}

\author{
Original scientific paper • Izvorni znanstveni rad \\ Received-prispjelo: 12. 12. 2018. \\ Accepted-prihvaćeno: 20. 11. 2019. \\ UDK: $630 * 814.111 ; 630 * 862.32 ; 630 * 892.4$ \\ https://doi.org/10.5552/drvind.2019.1854
}

\begin{abstract}
Depending on the use of wood in the forest industry, wood bark is mostly peeled and used as fuel. The ash and smoke left from the burned bark causes environmental pollution. The most environmentally friendly method for waste disposal is to convert waste into a valuable commodity. In this study, cherry tree bark was used as a dyestuff in paper production. Wild cherry (Cerasus avium L.) bark was boiled with water and KOH. The purpose of using $\mathrm{KOH}$ is to increase the solubility of the bark compounds. The chemi-thermomechanical pulp (CTMP) was dyed using the dyestuff. The alum mordant is used to fix the dyestuff. Paper can be exposed to external influences (mechanical, physical and biological) depending on the place of use. One of these effects is sunshine. When paper is exposed to direct or indirect sunlight, paper changes its color. Depending on the place of use, it is expected that the color of the paper will not be affected by the sunlight or that it will provide long-term strength after the application. Accelerated weathering test was chosen to measure the UV resistance of the dyestuff. The results have shown that the mordant has a significant effect on the fixation of dyestuff. After a total of 150 hours of weathering test, the color change was observed to be the lowest in the paper samples to which alum mordant was added to the dyestuff.
\end{abstract}

Keywords: wild cherry bark, chemical-thermomechanical pulp (CTMP), alum, weathering

SAŽETAK • Ovisno o uporabi drva u drvnoj industriji, kora drva uglavnom se ljušti i služi kao gorivo. Pepeo $i$ dim od spaljene kore onečišćuju okoliš. Najprikladnija ekološka metoda za zbrinjavanje otpada jest njegovo iskorištavanje u proizvodnji novih proizvoda. U ovom je istraživanju kora trešnjina drva upotrijebljena kao bojilo u proizvodnji papira. Kora divlje trešnje (Cerasus avium L.) kuhana je u smjesi vode i KOH. Zadaća KOH jest povećanje topljivosti spojeva u kori drva. Celuloza dobivena kemi-termomehaničkim postupkom (CTMP-om) obojena je uz pomoć bojila. Aluminijski fiksator upotrijebljen je za fiksiranje bojila. Papir može biti izložen vanjskim mehaničkim, fizičkim i biološkim utjecajima, ovisno o mjestu uporabe. Jedan o tih utjecaja je i Sunčeva svjetlost. Papir mijenja boju kada je izložen izravnoj i neizravnoj Sunčevoj svjetlosti. Pretpostavka je da o mjestu uporabe ovisi hoće li Sunčeva svjetlost utjecati na boju papira te hoće li papir zadržati čvrstoću tijekom dulje uporabe. Za mjerenje UV otpornosti bojila odabrano je njegovo ubrzano izlaganje vremenskim utjecajima. Prema rezultatima,

Authors are researchers at Bartin University, Faculty of Forestry, Department of Forest Industry Engineering, Bartin, Turkey.

Autori su istraživači Sveučilišta Bartin, Šumarski fakultet, Zavod za industriju u šumarstvu, Bartin, Turska. 
utvrđeno je da fiksator ima znatan utjecaj na fiksiranje bojila. Nakon 150 sati izlaganja ustanovljena je najmanja promjena boje na uzorcima papira obojenim bojilom koje sadržava aluminijski fiksator.

Ključne riječi: kora divlje trešnje, celuloza dobivena kemi-termomehaničkim postupkom (CTMP-om), aluminij, izlaganje vremenskim utjecajima

\section{INTRODUCTION}

1. UVOD

The bark is a cover that protects the tree trunk from external influences. Due to its low specific gravity, it plays an important role in the thermal insulation of the tree trunk and it constitutes an important part of the total body as biomass. In terms of anatomical and chemical properties, it has a very complex and different structure compared to wood. Some basic components do not show similarity to wood and therefore are not used as wood. In most application areas, the bark is stripped off before the wood is used. Studies on the industrial use of the bark are very limited. In fact, the bark is an important lowcost and abundantly available biomass. However, unsuitable fibers and some substances in its structure negatively affect its use. As a result, the use of the bark is problematic because it reduces the quality of woodbased products. For example, in fiberboard production, due to its cork-like structure, incomplete compression of the remaining bark in the fiber layer on the surface of the board, after hot-pressing, disrupts the smoothness of the surface by expanding (Suchsland and Woodson, 1986). In another study, it was stated that a small amount of bark, remaining in the pulp during paper production, caused fading and an unattractive appearance (Hale, 1969). In addition, when prunings from the kiwi (Actinidia deliciosa) plant were used in the production of paper pulp via the Kraft method, the color and mechanical properties of the paper were adversely affected by the bark (Gençer, 2015). Therefore, most wood is stripped of bark before production.

The amount of bark in plants varies according to species. Reddy and Yang (2009) determined the bark ratio as $20 \%$ in the stems of the cotton plant. Kiwi (Actinidia deliciosa) has been reported to have a bark ratio of $22 \%$ of dry wood weight (Gençer, 2015). When bark is considered as waste material, it represents a significant loss of biomass.

The bark, for which no significant industrial use can be found, is mostly burned after stripping to obtain energy. Although the combustion process is seen as a solution to energy production and to elimination of waste bark, the emissions into the atmosphere and some substances passing into the ash can be problematic in terms of gas and solid waste disposal (Stavropoulas, 1988). For this reason, waste should be conversed into useful products rather than burned. This would result in decreasing environmental pollution with a positive impact on the ecological balance.

Paper is traditionally dyed to make it visually appealing. In addition, publishing and printing operations are equipped with dyeing capabilities. There are many methods for the production of natural dyestuffs obtained from organic materials. Ethanol extraction was used to obtain dyestuff from walnut husk for dyeing silk thread
(Mirjalili et al., 2011). Dyestuff was obtained from leftover hazelnut waste (leaves, husks, shells and slash) via soaking in deionized water and a subsequent boiling process (Tutak and Benli, 2012). Feng et al. (2007) were successful in dyeing cotton and silk yarns using the roots of Rheum and Lithospermum erythrorhizon plants and reported in their study that they were able to produce UV-resistant clothing from the dyed yarn. In the paper and dyeing industries, the use of a mordant for color stability is common. Khan et al. (2016) used $\mathrm{Al}_{2} \mathrm{~K}_{2}\left(\mathrm{SO}_{4}\right) \cdot 24 \mathrm{H}_{2} \mathrm{O}$ as a mordant in the dyeing of wool yarn with walnut husk extract. Bechtold et al. (2007), using $\mathrm{Fe}_{2} \mathrm{SO}_{4} \cdot 7 \mathrm{H}_{2} \mathrm{O}$ as a mordant, achieved the darkest color with a dyestuff obtained from the hot water extract of the ash-tree bark. They stated that they dyed $1 \mathrm{~g}$ of wool yarn with 1-2 $g$ of dyestuff and that the increase of dyestuff ratio did not change the color tone. Gençer and Can (2016), in their study, obtained an organic dyestuff from the seeds of the elderberry plant (Sambucus nigra L.). They reported that upon dyeing paper, the use of alum as a mordant increased the color fastness. For these reasons, it is necessary to use an appropriate mordant in paper dyeing. Wild cherries grow naturally in Turkish forests. The wood has an appearance that is particularly preferred in the veneer, furniture and parquet industries. In one study, it is stated that the fibers fall within the averages of hardwood fibers and are suitable for the production of paper pulp using the Kraft method (Gençer and Gül Türkmen, 2016). In all of these applications, the bark is stripped and left unused.

The aim of this study was to dye paper by dyestuffs obtained from the wild cherry bark, which is used as fuel or left as waste in the forest industry sector. Alum $\left(\mathrm{AI}_{2} \mathrm{SO}_{4} \cdot 18 \mathrm{H}_{2} \mathrm{O}\right)$ was used as a mordant in order to examine the effect of the retention and fastness of the dyestuff. In the study, $\mathrm{KOH}$ was used to dissolve the tannin substances in the bark and to increase the soluble dye ratio. Although $\mathrm{NaOH}$ is generally used in solubility experiments, $\mathrm{Na}$ ions create saline waste water, which cannot be released in streams, lakes and seas without treatment (Zou et al., 2000). However, potassium is an important nutrient source for plants if used correctly. Gençer et al. (2006) reported that the black alkaline solution of $\mathrm{H}_{2} \mathrm{SO}_{4}$ and $\mathrm{P}_{2} \mathrm{O}_{5}$ left behind from paper pulp production using $\mathrm{KOH}$ and wheat stalks was applied as fertilizer after neutralization. Here $\mathrm{KOH}$ was chosen because it is less polluting.

\section{MATERIALS AND METHODS} 2. MATERIJALI I METODE

The bark stripped from wild cherry (Cerasus avium L.) wood was cut into $2 \mathrm{~cm}^{2}$ samples and left to air dry without exposure to direct sunlight. These samples were then kept in closed polyethylene bags for 24 $h$ to ensure that the moisture was balanced. At the end 
of this period, the damp bark samples were held in a drying oven for $24 \mathrm{~h}$ and the full dry bark weight was calculated. The full dry weight of the bark was calculated as $19 \%$ compared to the cherry wood. Due to structural differences of the bark and varying levels of the components, there is no standard method for bark analysis. In research studies to date, analysis has been carried out by alkali extraction or acid hydrolysis of extracted bark samples using nonpolar organic solvents and polar solvents. In producing the dyestuff, three different groups of dye were obtained from the cherry wood bark. To this purpose, $100 \mathrm{~g}$ of full dry weight bark was added to water only (Group I), to $1 \%$ $\mathrm{KOH}+$ water (Group II) and to $2 \% \mathrm{KOH}+$ water (Group III), and each was boiled for $4 \mathrm{~h}$. The experimental colored papers were attained by adding the cooled and strained dyestuff to the fiber suspension.

The pulp used in the paper production consisted of bleached chemical-thermo-mechanical pulp. In order to fully understand the effect of the dyestuff, control papers were produced from this pulp and the gloss of the papers was determined. There are three basic methods for adding dyestuff to paper: (1) the Hollander, (2) the glue process, and (3) the calendar for surface coating (Casey, 1960). Before obtaining the control papers and the dyestuff-colored papers, the pulps were kept in water for $24 \mathrm{~h}$ and hydrated. In order to open the pellets, each of the fiber suspensions prepared after this time was subjected to 10 min mixing in a Hollander beater with no load.

Cellulose fibers are negatively charged. They are treated with positively charged mordants to increase the bond by attracting negative and uncharged dyes by loading a positive charge (Casey, 1960). In the experiments using the mordant, alum $(1 \%$ or $2 \%$ based on oven-dried pulp) was first added to the Hollander with the loading of the fibers and mixed for $10 \mathrm{~min}$ to homogenize the suspension. Dyeing with the added alum ensured that the dye was distributed homogeneously when the dyestuff was added to the working Hollander. According to ISO 5269-2 (2013) standard, (70 \pm 2$) \mathrm{g} / \mathrm{m}^{2}$ grammage from the pulps of each sample group was used to produce six trial paper sheets using the Rapi-

Table 1 Dyestuff group conditions and percent of alum added to paper groups

Tablica 1. Skupine papira i bojila te postotni udio aluminijskog fiksatora

\begin{tabular}{|c|c|c|c|}
\hline $\begin{array}{l}\text { Paper groups } \\
\text { Skupine papira }\end{array}$ & $\begin{array}{c}\text { Dyestuff groups } \\
\text { Skupine bojila }\end{array}$ & $\mathbf{K O H}$ & $\begin{array}{c}\text { Alum } \\
\text { Aluminijski } \\
\text { fiksator }\end{array}$ \\
\hline 1 & - & - & - \\
\hline 2 & \multirow{3}{*}{ I } & - & - \\
\hline 3 & & - & $1 \%$ \\
\hline 4 & & - & $2 \%$ \\
\hline 5 & \multirow{3}{*}{ II } & $1 \%$ & - \\
\hline 6 & & $1 \%$ & $1 \%$ \\
\hline 7 & & $1 \%$ & $2 \%$ \\
\hline 8 & \multirow{3}{*}{ III } & $2 \%$ & - \\
\hline 9 & & $2 \%$ & $1 \%$ \\
\hline 10 & & $2 \%$ & $2 \%$ \\
\hline
\end{tabular}

tan-Köthen sheet former. The opacity values of these papers were determined according to the TAPPI T519 om-02 (2002) standard.

Table 1 shows the conditions for obtaining the dyestuff groups and the addition rates of alum to the papers.

Accelerated weathering testing was performed as per ASTM G53 (1988) using Q-Panel Lab Products equipment. The test medium was applied with $340 \mathrm{~nm}$ lamps set at $50{ }^{\circ} \mathrm{C}$. The UV light was applied at a light intensity of $0.85 \mathrm{~W} / \mathrm{m}^{2}$ for $24 \mathrm{~h}$. The color and opacity values of the samples were measured at time intervals of $10 \mathrm{~h}, 25 \mathrm{~h}, 50 \mathrm{~h}, 100 \mathrm{~h}$ and $150 \mathrm{~h}$ for a total of $150 \mathrm{~h}$. Three measurements were performed on each sample and then averaged. Using the Konica Minolta CD-600 color-measuring device, color measurement analyses were made on the test samples before and after the natural outdoor and accelerated outdoor environment testing in accordance with ISO 7724-2 (1984) standards. Color measurements were taken from three different points of the prepared samples and the average was used. Three samples were used for each variation.

The CIEL $a^{*} b^{*}$ (Commission Interationale de i'Eclairage) system consists of three variables (ISO 7724-2, 1984): $L^{*}$ (light stability), $a^{*}$ (red/green) and $b^{*}$ (yellow/blue). The chromatographic coordinates include $+a^{*}$ for red, $-a^{*}$ for green, $+b^{*}$ for yellow and $-b^{*}$ for blue. The $L^{*}, a^{*}$ and $b^{*}$ values were determined in the samples and the color changes were calculated according to the following Eqs. 1-4:

$$
\begin{gathered}
\Delta L^{*}=L_{\mathrm{f}}^{*}-L_{\mathrm{i}}^{*} \\
\Delta a^{*}=a_{\mathrm{f}}{ }^{*}-a_{\mathrm{i}}{ }^{*} \\
\Delta b^{*}=b_{\mathrm{f}}{ }^{*}-b_{\mathrm{i}}{ }^{*} \\
\Delta E^{*}=\left(\Delta L^{*} 2+\Delta a^{*} 2+\Delta b^{*} 2\right)^{1 / 2}
\end{gathered}
$$

Where $\Delta L^{*}, \Delta a^{*}$ and $\Delta b^{*}$ indicate the color changes $\left(\Delta E^{*}\right)$ that occur at the beginning (i) and at different time intervals (f). Low $\Delta E^{*}$ indicates color change or color stability.

Gloss measurements were made by using the light reflection capabilities of the test samples. Typically, there were no different results in the measurements of the surfaces with the same gloss characteristics. Generally, on glossy surfaces, surface gloss values are obtained by multiple measurements. Gloss measurements were taken using a gloss meter device at $60^{\circ}$.

The results of the weathering test were analyzed by one-way variance analysis (ANOVA) using the SPSS 16.0 program. The significance level $(P<0.05)$ between the variations was compared using Duncan homogeneity groups in which different letters, given along with the average values of the tested parameters, indicated a significant difference.

\section{RESULTS AND DISCUSSION} 3. REZULTATI I RASPRAVA

The color of the paper after dyeing with dyestuffs is expected to exhibit a fastness to light, stability to wa- 


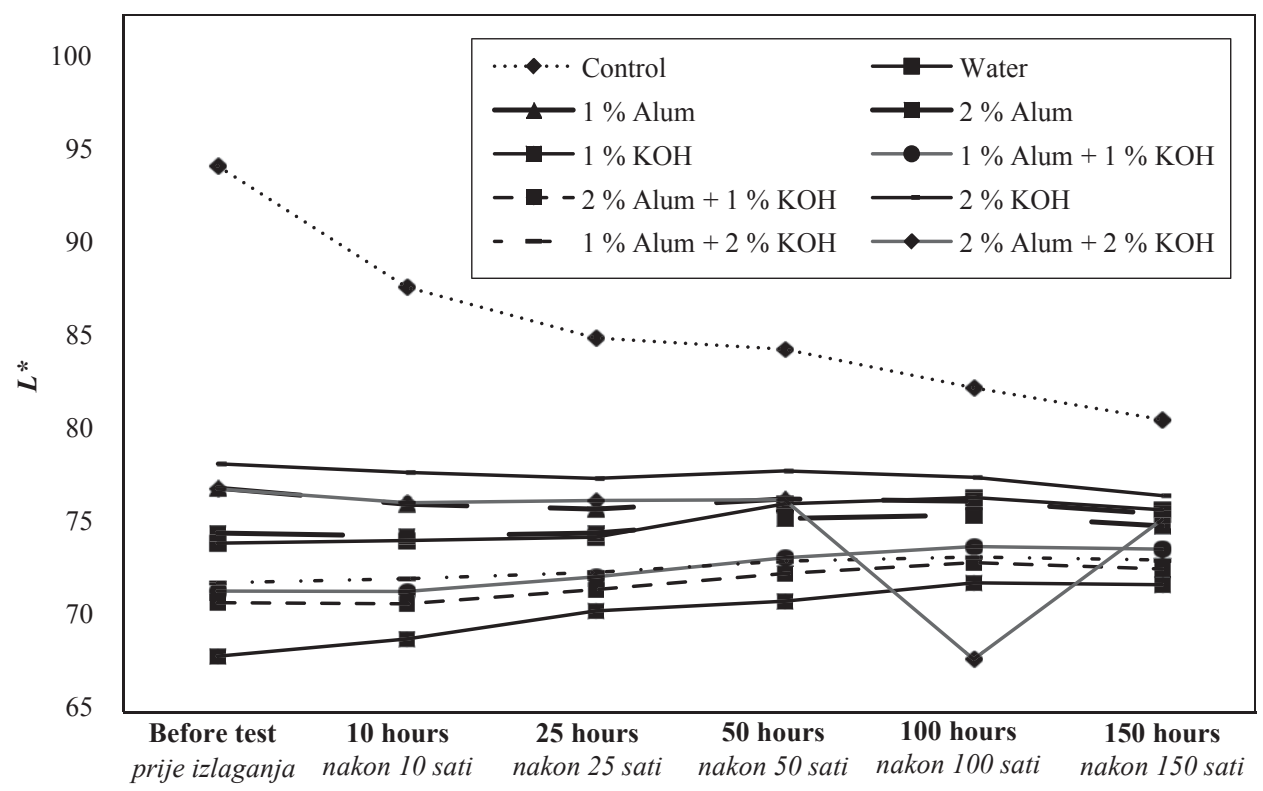

Figure 1 Light values $\left(L^{*}\right)$ of paper samples before and after weathering

Slika 1. Svjetlina $\left(L^{*}\right)$ uzoraka papira prije i nakon izlaganja vremenskim utjecajima

ter solubility, fastness to acid and alkali, and fastness to chlorine (Casey, 1960). In our study, light fastness was examined. The $L^{*}$ (light intensity) values determined in the test and control samples were calculated using the $a^{*}$ and $b^{*}$ chromatographic coordinates $\left(+a^{*}\right.$ red, $-a^{*}$ green, $+b^{*}$ yellow and $-b^{*}$ blue) in the CIEL* $a^{*} b^{*}$ system. The calculated $10,25,50,100,150 \mathrm{~h}$ accelerated aging values of $L^{*}, a^{*}, b^{*}$ and total color change $\left(\Delta E^{*}\right)$ are shown in Figures 1-4. The graphs were created based on the color change after a total of $150 \mathrm{~h}$.

The $L^{*}$ (light intensity) tends towards white as it approaches 100 and towards black when approaching 0 . The different ratios of alum added in the paper production to increase the color fastness and the $\mathrm{KOH}$ used in the boiling medium reduced the $L^{*}$ value. However, the $L^{*}$ values increased in these samples par- allel to the increase in weathering time. The light intensity in the control sample was 94.37, while in the sample from cherry wood bark boiled in $1 \% \mathrm{KOH}$, this ratio decreased to 68.01. Except for the $1 \% \mathrm{KOH}$ group, in other samples, the $L^{*}$ values decreased in parallel with the increase in the aging process time. The maximum reduction was obtained in the control samples, whereas the test samples showed nearly no reduction. Similar findings have been found in a previous study in which the $L^{*}$ values of the samples decreased with the effect of 72,144 , and $256 \mathrm{~h}$ of accelerated aging (Gençer et al., 2016). This finding is the result of the presence of carbonyl groups formed in the paper by the aging process; these carbonyl groups subsequently reduce the whiteness of the paper (Hon, 1981; Konuklar, 2011).

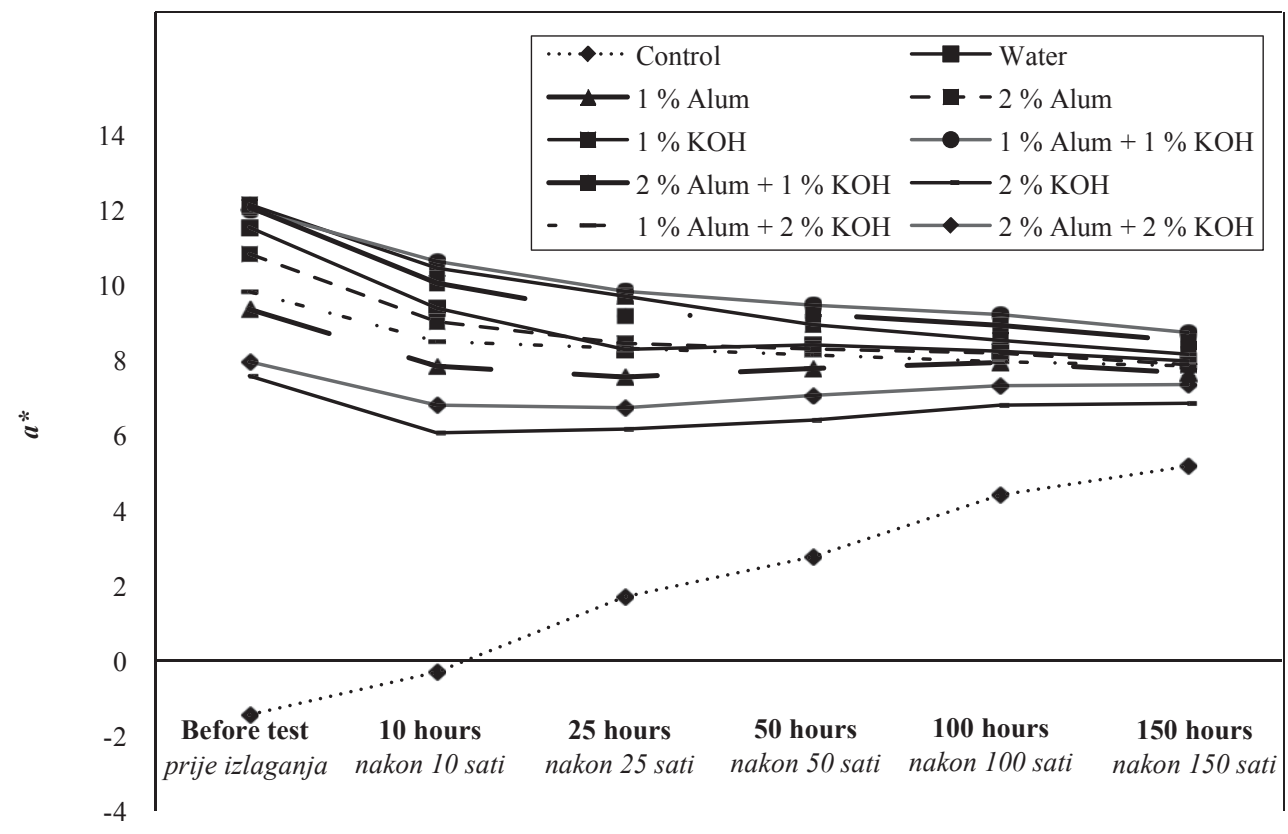

Figure 2 Red/green colors $\left(a^{*}\right)$ of paper samples before and after weathering

Slika 2. Crvena/zelena komponenta boje $\left(a^{*}\right)$ uzoraka papira prije i nakon izlaganja vremenskim utjecajima 


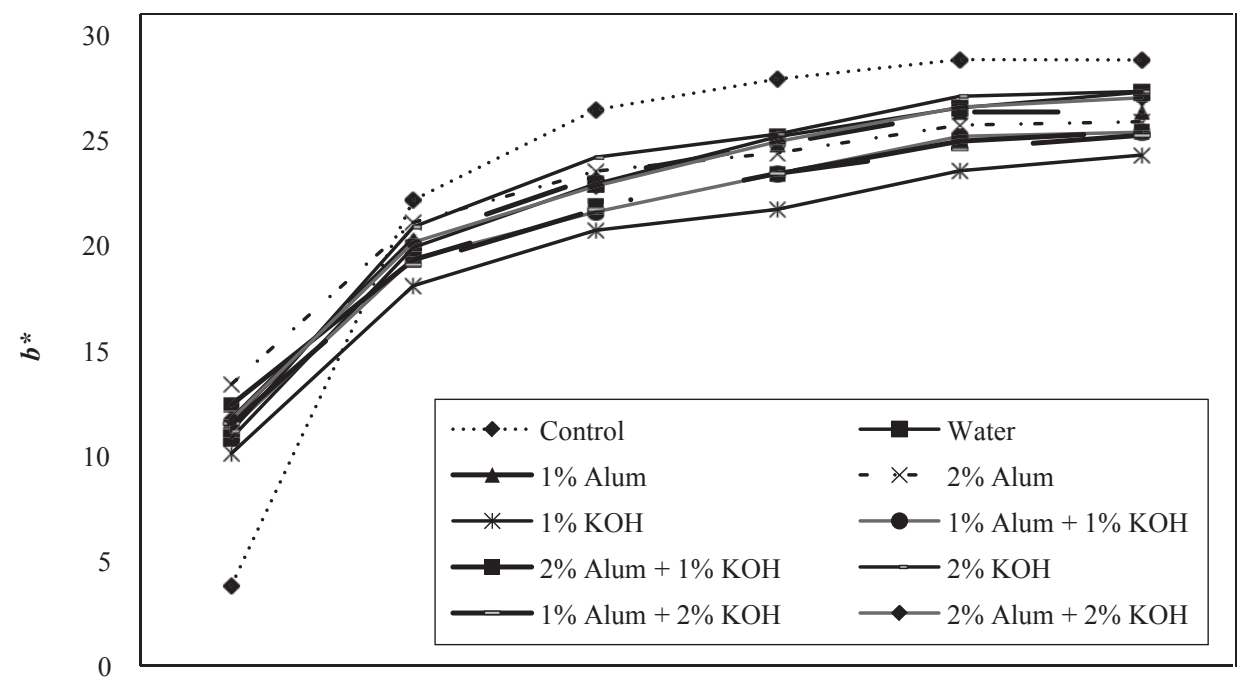

Figure 3 Yellow/blue colors $\left(b^{*}\right)$ of paper samples before and after weathering

Slika 3. Žuta/plava komponenta boje $\left(b^{*}\right)$ uzoraka papira prije i nakon izlaganja vremenskim utjecajima

When the $a^{*}$ value of the red/green color is examined, the $a^{*}$ value of -1.45 in the control samples varies between 7-12 with alum added and $\mathrm{KOH}$ used in the boiling medium during the paper production. The maximum value was obtained in the group with $1 \%$ alum $+1 \% \mathrm{KOH}$. As a result, the sample surfaces had a reddish color. Although the $a^{*}$ value of the control samples increased with the increase of the aging process at different duration times, the $a^{*}$ value of the test group samples decreased. The $a^{*}$ value of the control samples increased to 5.17 with the effect of UV light, while the $2 \% \mathrm{KOH}$ group decreased to 7.34 . In the case of UV aging for more than $150 \mathrm{~h}$, it was thought that the test and control group samples would intersect at the same $a^{*}$ value.

The increase in the $b^{*}$ value indicated that the samples tended toward yellow. The $+b^{*}$ value shows a tendency towards yellow, whereas the $-b^{*}$ shows a tendency towards blue color. During the paper production, the added alum and the $\mathrm{KOH}$ substances used in the boiling medium caused a slight yellowing in the color of the paper because the $b^{*}$ value in the control samples of 3.82 increased to 12.40 in the test samples (Figure 3). With the aging process, the yellowing of the paper increased. After a period of $100 \mathrm{~h}$, the $b^{*}$ values, which tended to increase, became stable. Thus, maximum yellowing was obtained in the control samples (28.82) after $100 \mathrm{~h}$.

Figure 4 shows the total color change values in the samples after $150 \mathrm{~h}$ of aging. At the end of $150 \mathrm{~h}$, color changes were observed in $29.23 \%$ of the control samples. In contrast, the total color change values of the samples produced with dyestuffs were significantly lower. In these sample groups, the total color change was reduced by $42 \%$ compared to the control samples. There was a decrease in total color change with the increase in alum ratio. With the addition of $2 \%$ alum, the total color change value dropped to 12.86 . According

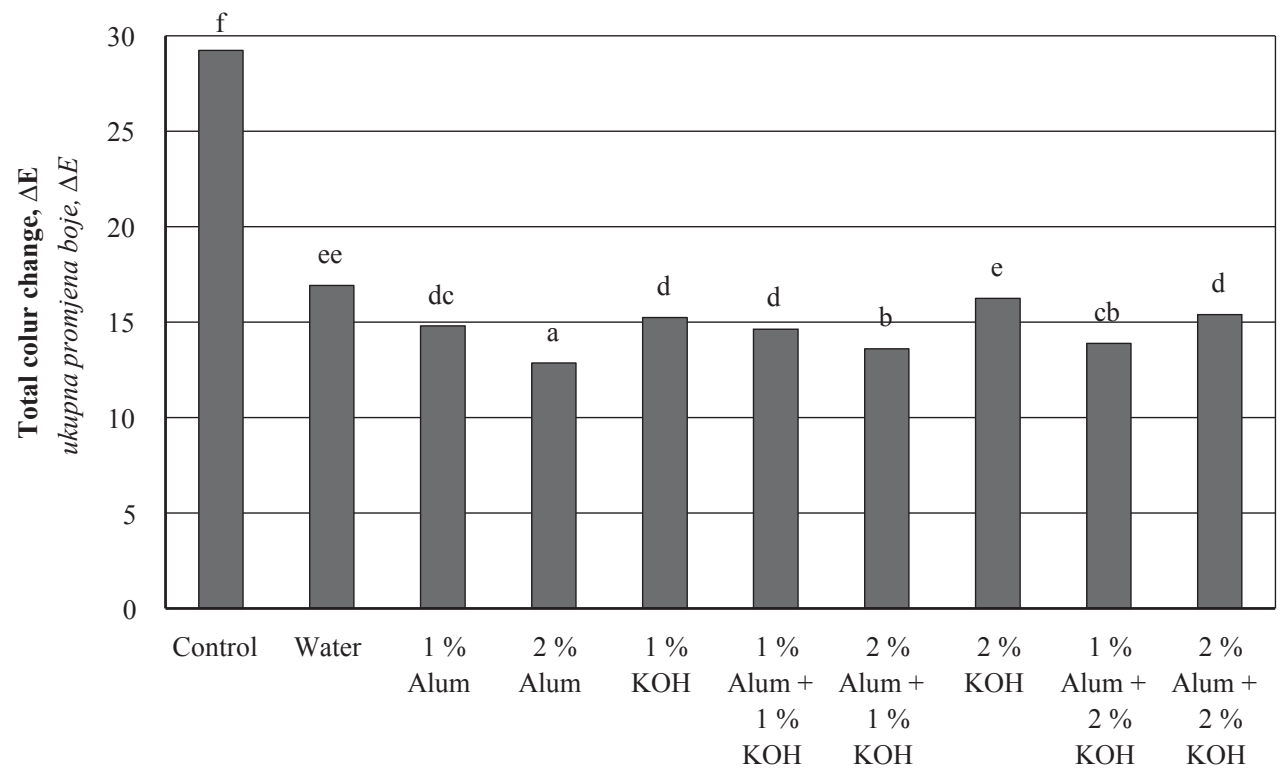

Figure 4 Total color changes of paper samples after weathering

Slika 4. Ukupna promjena boje uzoraka papira nakon izlaganja vremenskim utjecajima 
Table 2 Effect of aging on paper gloss change $\left(60^{\circ}\right)$

Tablica 2. Utjecaj starenja na promjenu sjaja papira $\left(60^{\circ}\right)$

\begin{tabular}{|l|c|c|c|c|c|c|}
\hline & $\begin{array}{c}\text { Before test } \\
\text { Prije } \\
\text { izlaganja }\end{array}$ & $\begin{array}{c}\mathbf{1 0} \text { hours } \\
\text { Nakon 10 sati }\end{array}$ & $\begin{array}{c}\mathbf{2 5} \text { hours } \\
\text { Nakon 25 sati }\end{array}$ & $\begin{array}{c}\mathbf{5 0} \text { hours } \\
\text { Nakon 50 sati }\end{array}$ & $\begin{array}{c}\mathbf{1 0 0} \text { hours } \\
\text { Nakon 100 } \\
\text { sati }\end{array}$ & $\begin{array}{c}\text { 150 hours } \\
\text { Nakon 150 } \\
\text { sati }\end{array}$ \\
\hline \multirow{2}{*}{ Water } & $\begin{array}{c}36.46 \\
(0.05) \mathrm{dcb}\end{array}$ & $\begin{array}{c}12.50 \\
(0.05) \mathrm{d}\end{array}$ & $\begin{array}{c}12.50 \\
(0.05) \mathrm{d}\end{array}$ & $\begin{array}{c}18.30 \\
(0.05) \mathrm{dcb}\end{array}$ & $\begin{array}{c}17.76 \\
(0.05) \mathrm{cb}\end{array}$ & $\begin{array}{c}16.33 \\
(0.10) \mathrm{cb}\end{array}$ \\
\hline \multirow{2}{*}{$1 \%$ Alum } & 31.77 & 5.88 & 5.88 & 15.03 & 14.47 & 13.61 \\
$(0.05) \mathrm{ed}$ & $(0.05) \mathrm{f}$ & $(0.05) \mathrm{f}$ & $(0.15) \mathrm{dc}$ & $(0.25) \mathrm{cb}$ & $(0.25) \mathrm{cb}$ \\
\hline \multirow{2}{*}{$2 \%$ Alum } & 42.71 & 21.32 & 21.32 & 26.14 & 23.68 & 22.45 \\
& $(0.05) \mathrm{ba}$ & $(0.05) \mathrm{b}$ & $(0.05) \mathrm{b}$ & $(0.15) \mathrm{ba}$ & $(0.15) \mathrm{ba}$ & $(0.10) \mathrm{ba}$ \\
\hline \multirow{2}{*}{$1 \% \mathrm{KOH}$} & 36.98 & 13.24 & 12.24 & 18.30 & 16.45 & 14.29 \\
& $(0.11) \mathrm{dcb}$ & $(0.11) \mathrm{d}$ & $(0.05 \mathrm{~d}$ & $(0.05) \mathrm{dcb}$ & $(0.05) \mathrm{cb}$ & $(0.00) \mathrm{cb}$ \\
\hline \multirow{2}{*}{$1 \%$ Alum $+1 \% \mathrm{KOH}$} & 45.83 & 25.74 & 25.74 & 31.37 & 30.92 & 28.57 \\
$2 \%$ Alum $+1 \% \mathrm{KOH}$ & $(0.05) \mathrm{a}$ & $(0.05) \mathrm{a}$ & $(0.05) \mathrm{a}$ & $(0.00) \mathrm{a}$ & $(0.01) \mathrm{a}$ & $(0.10) \mathrm{a}$ \\
\hline \multirow{2}{*}{$2 \% \mathrm{KOH}$} & 40.63 & 18.38 & 18.38 & 23.53 & 22.37 & 20.41 \\
& $(0.00) \mathrm{cba}$ & $(0.00) \mathrm{c}$ & $(0.05) \mathrm{c}$ & $(0.00) \mathrm{ba}$ & $(0.05) \mathrm{cba}$ & $(0.10) \mathrm{cba}$ \\
\hline \multirow{2}{*}{$1 \%$ Alum $+2 \% \mathrm{KOH}$} & 29.69 & 2.94 & 2.94 & 12.42 & 11.84 & 10.88 \\
& $(0.00) \mathrm{e}$ & $(0.00) \mathrm{g}$ & $(0.05) \mathrm{g}$ & $(0.05) \mathrm{d}$ & $(0.05) \mathrm{c}$ & $(0.05) \mathrm{c}$ \\
\hline \multirow{2}{*}{$2 \%$ Alum $+2 \% \mathrm{KOH}$} & 34.38 & 9.56 & 9.56 & 17.65 & 15.79 & 14.29 \\
& $(0.00) \mathrm{edc}$ & $(0.00) \mathrm{e}$ & $(0.05) \mathrm{e}$ & $(0.00) \mathrm{dcb}$ & $(0.05) \mathrm{cb}$ & $(0.00) \mathrm{cb}$ \\
\hline
\end{tabular}

* Values in parentheses: Standard deviation. / Vrijednosti u zagradama standardna su devijacija.

Letters in columns: Duncan test results./ Slova u stupcima označavaju rezultate Duncanova testa.

to statistical analysis results, with the use of $2 \%$ alum, the total color change differed from the other groups. There was a slight increase in the total color change in the papers that were boiled in $1-2 \% \mathrm{KOH}$ medium and the values obtained were near to those of the papers produced by boiling in the water medium. Thus, the boiling medium had no significant effect on total color change. However, Ali et al. (2009), in their study on the effects of dyestuff from the henna plant obtained via alkaline and deionized water extraction, reported that the alkaline yielded a stronger color in the dyeing of cotton yarn. The carbonyl and carboxyl groups in the paper act on the color of the paper (Konuklar, 2011). Hence, the dyestuff of the dye material alone led to the modification of these bonds, resulting in a decrease in total color change.

Table 2 shows the change in gloss values of the test samples with the aging process as compared to the initial gloss values. Before the weathering test, the lowest gloss value was statistically calculated in the $1 \%$ alum $+1 \% \mathrm{KOH}$ samples, while the highest gloss value was obtained in the control samples. The maximum change in gloss values was obtained in the control samples. The gloss values of the control samples decreased by $29.22 \%$ in the first $10 \mathrm{~h}$, and at the end of $150 \mathrm{~h}$, there was a decrease of $23.44 \%$ in gloss. Parallel to the increase in weathering time and the decrease of the gloss value of the control samples, with the weathering process, the color change in the lignin caused the gloss to decrease. The glossiness of test samples did not change significantly after $150 \mathrm{~h}$. Generally, a similar situation was observed in all test samples. Alum and $\mathrm{KOH}$ substances are thought to increase the gloss of paper. In one study it was stated that, with the aging process, the control papers could not maintain the gloss values, while the test samples provided a certain gloss stability (Peşman,
2010). Table 3 shows the opacity values of paper samples before and after aging.

No significant change in opacity of control samples was observed in the first $10 \mathrm{~h}$ of aging. However, statistically, there were differences between the control and test samples. The opacity values of the paper decreased significantly with $25 \mathrm{~h}$ of the aging process, with the maximum reduction obtained in the $1 \% \mathrm{KOH}$ samples.

Although the opacity value of the control samples was $93.58 \%$, the opacity value of $96.94 \%$ for the paper in Group I produced from dyestuff without mordant was increased to $98.22 \%$ with the use of $1 \%$ mordant and to $96.50 \%$ with $2 \%$ mordant. In Group II, the opacity decreased from $98.60 \%$ to $98.12 \%$ when $1 \%$ mordant was used, but increased to $99.35 \%$ when $2 \%$ mordant was added. The opacity of the paper in Group III obtained from dyestuffs without mordant was 98.47 $\%$, which increased to $99.07 \%$ with the use of $1 \%$ mordant, while decreasing to $97.95 \%$ when $2 \%$ mordant was used. However, these decreases were not statistically significant.

According to these results, the $\mathrm{KOH}$ added to obtain the dyestuff was not effective in the bonding of the dyestuff. Therefore, we believe that only water should be used in the dyeing process. Disintegration of the fibers along with the aging process and the yellowing of the paper were thought to reduce opacity values (Clark, 1978).

Statistical analysis revealed that opacity values differed from the control with the addition of $2 \%$ alum and $1-2 \% \mathrm{KOH}$. It was also observed that the first $10 \mathrm{~h}$ weathering process decreased the opacity by a statistically significant amount. However, after $25 \mathrm{~h}$ of weathering, the opacity values of the control samples increased. As for maintaining the opacity values of the samples after $150 \mathrm{~h}$ 
...... Gençer, Can, Mustak, Gitti: The Effect of Using Alum Mordant in Wild Cherry Bark...

Table 3 Effect of aging on paper opacity

Tablica 3. Utjecaj starenja na neprozirnost papira

\begin{tabular}{|l|c|c|c|c|c|c|}
\hline & $\begin{array}{c}\text { Before test } \\
\text { Prije } \\
\text { izlaganja }\end{array}$ & $\begin{array}{c}\mathbf{1 0} \text { hours } \\
\text { Nakon 10 sati }\end{array}$ & $\begin{array}{c}\mathbf{2 5} \text { hours } \\
\text { Nakon 25 sati }\end{array}$ & $\begin{array}{c}\mathbf{5 0} \text { hours } \\
\text { Nakon 50 sati }\end{array}$ & $\begin{array}{c}\mathbf{1 0 0} \text { hours } \\
\text { Nakon } \\
100 \text { sati }\end{array}$ & $\begin{array}{c}\text { 150 hours } \\
\text { Nakon } \\
150 \text { sati }\end{array}$ \\
\hline \multirow{2}{*}{ Control } & $93.58 \mathrm{a} *$ & $94.49 \mathrm{a}$ & $84.00 \mathrm{~h}$ & $100.00 \mathrm{e}$ & $99.52 \mathrm{e}$ & $96.68 \mathrm{a}$ \\
& $(0.36)$ & $(0.16)$ & $(0.47)$ & $(0.00)$ & $(0.81)$ & $(0.98)$ \\
\hline \multirow{2}{*}{ Water } & $96.94 \mathrm{ba}$ & $98.49 \mathrm{c}$ & $64.56 \mathrm{e}$ & $95.17 \mathrm{c}$ & $93.41 \mathrm{c}$ & $96.95 \mathrm{a}$ \\
& $(6.54)$ & $(0.42)$ & $(0.88)$ & $(1.01)$ & $(0.56)$ & $(0.11)$ \\
\hline \multirow{2}{*}{$1 \%$ Alum } & $98.22 \mathrm{ba}$ & $97.24 \mathrm{~b}$ & $66.83 \mathrm{f}$ & $97.54 \mathrm{~d}$ & $95.33 \mathrm{~d}$ & $98.16 \mathrm{cb}$ \\
& $(4.03)$ & $(0.90)$ & $(0.35)$ & $(0.12)$ & $(0.37)$ & $(0.34)$ \\
\hline \multirow{2}{*}{$2 \%$ Alum } & $96.5 \mathrm{~b}$ & $98.98 \mathrm{edc}$ & $63.73 \mathrm{~d}$ & $94.67 \mathrm{c}$ & $93.66 \mathrm{c}$ & $98.29 \mathrm{cb}$ \\
& $(1.42)$ & $(0.88)$ & $(0.31)$ & $(0.18)$ & $(0.20)$ & $(0.53)$ \\
\hline \multirow{2}{*}{$1 \% \mathrm{KOH}$} & $98.6 \mathrm{~b}$ & $99.90 \mathrm{f}$ & $56.51 \mathrm{a}$ & $82.68 \mathrm{a}$ & $84.04 \mathrm{a}$ & $99.33 \mathrm{~d}$ \\
& $(0.96)$ & $(0.00)$ & $(0.01)$ & $(1.70)$ & $(1.36)$ & $(0.38)$ \\
\hline \multirow{2}{*}{$1 \%$ Alum $+1 \% \mathrm{KOH}$} & $98.12 \mathrm{~b}$ & $99.77 \mathrm{fe}$ & $60.49 \mathrm{c}$ & $87.37 \mathrm{~b}$ & $86.55 \mathrm{~b}$ & $99.48 \mathrm{~d}$ \\
& $(1.04)$ & $(0.17)$ & $(0.09)$ & $(1.76)$ & $(1.40)$ & $(0.80)$ \\
\hline \multirow{2}{*}{$2 \%$ Alum $+1 \% \mathrm{KOH}$} & $99.35 \mathrm{~b}$ & $99.61 \mathrm{fed}$ & $58.82 \mathrm{~b}$ & $87.35 \mathrm{~b}$ & $87.77 \mathrm{~b}$ & $99.69 \mathrm{~d}$ \\
& $(0.77)$ & $(0.09)$ & $(0.62)$ & $(1.32)$ & $(1.72)$ & $(0.15)$ \\
\hline \multirow{2}{*}{$2 \% \mathrm{KOH}$} & $98.47 \mathrm{~b}$ & $98.41 \mathrm{c}$ & $70.37 \mathrm{~g}$ & $100.00 \mathrm{e}$ & $99.09 \mathrm{e}$ & $97.99 \mathrm{~b}$ \\
& $(0.72)$ & $(0.23)$ & $(0.42)$ & $(0.00)$ & $(0.79)$ & $(0.17)$ \\
\hline \multirow{2}{*}{$1 \%$ Alum $+2 \% \mathrm{KOH}$} & $99.07 \mathrm{~b}$ & $98.83 \mathrm{dc}$ & $59.60 \mathrm{~b}$ & $88.71 \mathrm{~b}$ & $92.88 \mathrm{c}$ & $98.34 \mathrm{dc}$ \\
& $(0.12)$ & $(0.42)$ & $(0.55)$ & $(0.12)$ & $(0.29)$ & $(0.20)$ \\
\hline \multirow{2}{*}{$2 \%$ Alum $+2 \% \mathrm{KOH}$} & $97.95 \mathrm{~b}$ & $98.68 \mathrm{c}$ & $67.60 \mathrm{f}$ & $98.05 \mathrm{~d}$ & $99.98 \mathrm{e}$ & $98.35 \mathrm{cb}$ \\
& $(0.05)$ & $(0.11)$ & $(0.30)$ & $(0.28)$ & $(0.00)$ & $(0.20)$ \\
\hline
\end{tabular}

* Values in parentheses: Standard deviation. / Vrijednosti u zagradama standardna su devijacija.

Letters in columns: Duncan test results. / Slova u stupcima označavaju rezultate Duncanova testa.

of weathering, no statistical difference was found between the individual use of $1 \%$ or $2 \%$ alum.

\section{CONCLUSIONS}

\section{ZAKLJUČAK}

Dyestuff was used for dyeing bleached pulp produced via the chemical-thermo-mechanical pulp (CTMP) method. In order to obtain dyestuff, the bark, water and $\mathrm{KOH}$ were used in addition to alum as a mordant to increase the color fastness. According to the accelerated aging results, it was observed that the alum had a significant effect on total color change. The statistical analysis results of the total color change values support this case. The medium in which the cherry wood bark was boiled (water, 1-2 \% $\mathrm{KOH}$ ) had an effect on total color change; however, this was not significant at the $95 \%$ confidence interval.

It was observed that the gloss of the cherry wood bark paper was significantly preserved. No significant change occurred in the first $25 \mathrm{~h}$, while slight changes occurred in the gloss values after $25 \mathrm{~h}$. After $150 \mathrm{~h}$ of weathering, the minimum gloss value was found in the $1 \%$ Alum $+1 \% \mathrm{KOH}$ group. The opacity values of papers produced using alum and $\mathrm{KOH}$ differed from the control samples before the weathering test, although statistically there was no significant difference between them. However, with 150 hours of the weathering process, they exhibited different opacity behaviors. In all media, the maximum opacity value was obtained with $1 \% \mathrm{KOH}$. Therefore, it can be said that the use of $1 \% \mathrm{KOH}$ in the production of the dyestuff increased the ratio of dyestuff extracted from the bark.

\section{REFERENCES}

5. LITERATURA

1. Ali, S.; Hussain, T.; Nawaz, R. 2009: Optimization of alkaline extraction of natural dye from Henna leaves and its dyeing on cotton by exhaust method. Journal of Cleaner Production, 17 (1): 61-66.

https://doi.org/10.1016/j.jclepro.2008.03.002.

2. Bechtold, T.; Mahmud-Ali, A.; Mussak, R. A., 2007: Reuse of ash-tree (Fraxinus excelsior L.) bark as natural dyes for textile dyeing: Process conditions and process stability. Coloration Technology, 123 (4): 271-279. https://doi.org/10.1111/j.1478-4408.2007.00095.x.

3. Casey, J. P., 1960: Pulp and Paper Chemistry and Chemical Technology II. New York: Interscience Publishers, Inc., pp. 955-1000.

4. Clark, J. D. A., 1978: Fibrillation and fiber bonding. Pulp technology and treatment for paper (A Pulp and Paper Book). M. Freeman Publications, pp. 160-180.

5. Feng, X. X.; Zhang, L. L.; Chen, J. Y.; Zhang, J. C., 2007: New insights into solar UV-protective properties of natural dye. Journal of Cleaner Production, 15 (4): 366-372. https://doi.org/10.1016/j.jclepro.2005.11.003.

6. Gençer, A., 2015: The utilization of Kiwi (Actinidia deliciosa) prunings waste for kraft paper and the effect of the bark on paper properties. Drewno, 58 (194): 103-113. https://doi.org/10.12841/wood.1644-3985.084.08.

7. Gencer, A.; Can, A., 2016: Investigation of dyestuff obtained from Elderberry (Sambucus Nigra L.) Seeds in the coloring Process of Paper. International Forestry Symposium (IFS 2016), pp. 736-740, 07-10 December 2016, Kastamonu, Turkey.

8. Gençer, A.; Gül Türkmen, H., 2016: Determination of paper production conditions of wild cherry heartwood and sapwood. Journal of Bartın Faculty of Forestry, 18 (1): 23-31. 
9. Gencer, A.; Eroğlu, H.; Karakurt, H., 2006: Utilization of Black Liquor from KOH-Air Paper Pulp Production Method as a Fertilizer in Broad Beans (Vicia faba) Cultivation. Ecology, 15 (61): 56-60

10. Gencer, A.; Onat, S. M.; Can, A.; Ozgül, U.; Sivrikaya, H.; Yurdakurban, F., 2016: Effect of sodium ascorbate on weathering performance of $\mathrm{NaOH}$ pulping and paper. Drewno, 59 (198): 49-60. https://doi.org/10.12841/wood.1644-3985.171.11.

11. Hale, D. J., 1969: Pulp and Paper Manufacture, $2^{\text {nd }}$ ed., vol. I. The Pulping of Wood. McGraw-Hill Book Company.

12. Hon, D., 1981: Yellowing of Modern Papers, Preservation of Paper and Textiles of Historic and Artistic Value. American Chemical Society. Advances in Chemistry, 193, Chapter 10: 119-141. https://doi.org/10.1021/ba-1981-0193.ch010.

13. Khan, M. A.; U1-Islam, S.; Mohammad, F., 2016: Extraction of natural dye from walnut bark and its dyeing properties on wool yarn. Journal of Natural Fibers, 13 (4): 458469. https://doi.org/10.1080/15440478.2015.1055033.

14. Konuklar, M., 2011: A new method investigation of paper conservation, Doctoral thesis. Ankara University, Institute of Natural and Applied Sciences, Ankara.

15. Mirjalili, M.; Nazarpoor, K.; Karimi, L., 2011: Extraction and identification of dye from walnut green husks for silk dyeing. Asian Journal of Chemistry, 23 (3): 1055.

16. Peșman, E., 2010: Determination of ink removal and bleaching properties of old news and magazine papers, Doctoral thesis. Karadeniz Technical University, Institute of Natural and Applied Sciences, Trabzon.

17. Reddy, N.; Yang, Y., 2009: Properties and potential applications of natural cellulose fibers from the bark of the cotton stalks. Bioresource Technology, 100 (14): 35633569. https://doi.org/10.1016/j.biortech.2009.02.047.
18. Stavropoulas, W. S., 1988: What can packaging manufacturers do about munipical solid waste? TAPPI Journal, 71 (3): 209-211.

19. Suchsland, O.; Woodson, G. E., 1986: Fiberboard Manufacturing Practices in the United States. United States Department of Agriculture, Forest Service, Agriculture Handbook No. 640: 263

20. Tutak, M.; Benli, H., 2012: Dyeing properties of textiles by Turkish hazelnut (Corylus colurna): leaves, coat, shell and dice. Coloration Technology, 128 (6): 454-458. https://doi.org/10.1111/j.1478-4408.2012.00399.x.

21. Zou, H.; Liukkonen, B.; Genco, C. J.; Miller, W., 2000: Influence of kraft pulping on the kinetics of oxygen delignification. TAPPI Journal, 83 (2): 65-71.

22. ***ASTM G53, 1988: Standard practice for operating light and water exposure apparatus for exposure of nonmetallic materials. ${ }^{* * *}$ ISO 5269-2, 2013: Pulps preparation of laboratory sheets for physical testing. Part 2: Rapid-Köthem method.

23. ***ISO 7724-2, 1984: Paints and varnishes-Colorimetry. Part 2: Color measurement, ISO Standard.

24. ***TAPPI T519 om-02, 2002: Diffuse Opacity of Paper (d/0 paper backing).

\section{Corresponding address:}

\section{AHMET CAN}

Bartin University

Faculty of Forestry

Department of Forest Industrial Engineering

74100 Bartin, TURKEY

e-mail: acan@bartin.edu.tr; 6116acan@gmail.com 